\title{
Clinical Reasoning: Seven-year-old girl with progressive gait difficulties
}

Jillian Alderson, MD, and Partha S. Ghosh, MD

Correspondence

Neurology ${ }^{\circledR}$ 2020;94:364-367. doi:10.1212/WNL.0000000000009003

Dr. Ghosh

partha.ghosh@

childrens.harvard.edu

\section{Section 1}

A 7-year-old girl from a middle eastern country was referred for progressive gait difficulties. She was born full-term. She was able to run, climb stairs, and keep up with other children until age 6 . She began to hyperextend her right knee and evert her right foot while walking, leading to falls, and her symptoms progressed to the left leg in about 6 months. Within 1 year after symptom onset, she was no longer able to walk independently. There was no diurnal variation of her symptoms. There was some decline in language and cognitive functions. Her parents were first cousins and 3 of her mother's sisters and 1 brother had gait difficulty beginning in their teens, which worsened; all of them used assistive devices. The parents and the patient's 3 siblings (younger and older) were unaffected.

General examination was unremarkable without obvious dysmorphic facial features. Neurologic examination revealed normal cranial nerves. Cognition and speech were difficult to assess due to language barrier. The patient had increased muscle tone (mostly rigidity), lower limbs > upper limbs. Muscle power was normal in all proximal and distal limb muscles and tendon reflexes were brisk (3+). During finger-nose testing, there was terminal dysmetria, though it was difficult to determine if it was related to dystonic posturing. She had truncal dystonia and used sensory tricks to keep her stable in the sitting posture. She had striatal toes. There were no tremors, choreoathetosis, masked facies, or orolingual dystonia.

\section{Questions for consideration:}

1. What are the differential diagnoses in this case?

2. What tests could narrow the differential diagnosis in this case?

\section{GO TO SECTION 2}




\section{Section 2}

The patient presented with progressive gait difficulties for a year. The predominant clinical finding was dystonia localizing to the extrapyramidal system and possible pyramidal tract (hyperreflexia) and cortical involvement (cognitive and speech decline). Dystonia is a movement disorder characterized by sustained or intermittent muscle contraction causing abnormal movements or postures. Dystonia is one of the commonest hyperkinetic movement disorders in children. ${ }^{1}$ It is important to clinically characterize dystonia based on the age at onset, body distribution (focal, segmental, or generalized), and temporal course (persistent, paroxysmal, static vs progressive course). ${ }^{1}$ Dystonia can be isolated (pure), combined (associated with other movement disorders), or complex (neurologic or systemic abnormalities).

The differential diagnoses of childhood dystonia are vast and complex. The most common causes are acquired and include cerebral palsy, stroke, neoplasm, medications, autoimmune encephalopathies, and psychogenic causes. ${ }^{1-3}$

The child presented here had a progressive course with generalized dystonia due to an autosomal recessive disorder based on the family history. Brain MRI may be helpful early in the course in narrowing the differential by ruling out structural lesions and providing clues to genetic etiologies of dystonia. ${ }^{1}$ T2 hyperintense lesions in the extrapyramidal system are seen in Wilson disease, mitochondrial encephalopathy, thiamine transporter deficiency syndromes, pyruvate dehydrogenase deficiency, or organic acidurias. T2 hypointense lesions are seen in neurodegeneration with brain iron accumulation (NBIA). T1 hyperintensity is seen in brain manganese accumulation. Calcifications are seen in Aicardi-Goutières syndrome and primary familial brain calcification and caudate atrophy is seen in Huntington disease and neuroacanthocytosis. ${ }^{1}$ Another important test that is helpful is an ophthalmologic examination to look for findings like Kayser-Fleischer rings, retinitis pigmentosa, or optic atrophy. Our patient did not have any of those findings.

Brain MRI in this patient showed symmetrical T2 hypointensity in the bilateral globus pallidus (GP) (white arrows in figure) and mild cerebral atrophy (prominent sulci) in keeping with NBIA. MRI brain helped us to narrow the differential diagnosis of dystonia in this case.

NBIA comprises a group of clinically and genetically heterogeneous neurodegenerative disorders characterized by iron overload, which mainly accumulates in the basal ganglia structures (GP and substantia nigra [SN]), and sometimes cortex and cerebellum in the most severe subtypes. ${ }^{4,5}$ NBIA can be inherited as autosomal recessive, dominant, or X-linked trait, resulting in prominent extrapyramidal manifestations (dystonia, parkinsonism) and other neurologic abnormalities like spasticity, neuropsychiatric abnormalities, optic atrophy, or retinal degeneration. ${ }^{1}$ These are rare disorders with an estimated
Figure MRI brain

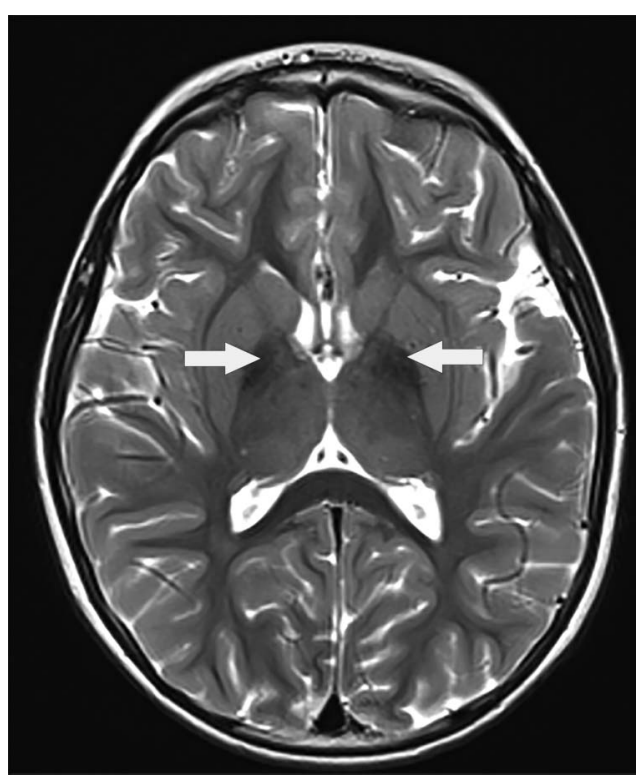

Axial T2 images show bilateral hypointense lesions within the globus pallidus (arrows) and mild cerebral atrophy.

prevalence of 1-3 per million and can present from infancy to adulthood with variable degree of progression. ${ }^{4}$ To date, 12 genes have been linked to NBIA (PANK2, COASY, PLA2G6, C19orf12, FA2H, ATP13A2, WD repeat domain 45 (WDR45), DCAF17, SCP2, GTPBP2, FTL, and CP); however, about $15 \%-20 \%$ of patients remain genetically undefined (table) ${ }^{4-6}$

Pantothenate kinase-associated neurodegeneration (PKAN) is the prototype and most common form of NBIA, accounting for about $50 \%$ of all NBIA cases. It is an autosomal recessive disorder due to mutations of the PANK2 gene. PKAN can present as an early-onset classical form or the late-onset atypical form. ${ }^{4}$ Clinical features include dystonia, spasticity, ataxia, cognitive decline, optic atrophy, and retinitis pigmentosa. The classic brain MRI pattern is called eye of the tiger sign, consisting of abnormal T2 hypointensity in the GP with a longitudinal stripe of $\mathrm{T} 2$ hyperintensity (due to gliosis and spongiosis) in T2-weighted images. ${ }^{4}$ Lack of ophthalmologic and classic MRI findings made PKAN less likely in this case. COASY protein-associated neurodegeneration is caused due to mutation in the COASY gene, which encodes for CoA synthase. Clinical features include oromandibular dystonia with dysarthria, spastic dystonic paraparesis, severe spastic bradykinetic-rigid syndrome, and distal areflexia in the lower limbs (our patient had brisk reflexes). ${ }^{4}$ PLA2G6-associated neurodegeneration due to mutation of the PLA2G6 gene consists of classic infantile neuroaxonal dystrophy (INAD) and atypical neuroaxonal dystrophy. The former is characterized by early-onset hypotonia, gait disturbance, cerebellar ataxia, pyramidal signs, and early optic atrophy. ${ }^{4,5}$ Our patient had disease onset at 6 years of age and there was no optic atrophy, making INAD less likely. Mitochondrial membrane 
Table Salient features of the neurodegeneration with brain iron accumulation disorders

\begin{tabular}{|c|c|c|c|c|}
\hline Disorder & $\begin{array}{l}\text { Gene } \\
\text { mutation }\end{array}$ & $\begin{array}{l}\text { Mode of } \\
\text { inheritance }\end{array}$ & Clinical manifestations & $\begin{array}{l}\text { Key distinguishing } \\
\text { characteristics }\end{array}$ \\
\hline $\begin{array}{l}\text { Pantothenate } \\
\text { kinase-associated } \\
\text { neurodegeneration }\end{array}$ & $\begin{array}{l}\text { PANK2 on } \\
20 \mathrm{p} 13\end{array}$ & $\begin{array}{l}\text { Autosomal } \\
\text { recessive }\end{array}$ & $\begin{array}{l}\text { Dystonia, spasticity, ataxia, cognitive decline, optic } \\
\text { atrophy, and retinitis pigmentosa }\end{array}$ & $\begin{array}{l}\text { Accounts for about } 50 \% \text { of all } \\
\text { cases; MRI with eye of the tiger } \\
\text { sign }\end{array}$ \\
\hline $\begin{array}{l}\text { COASY } \\
\text { protein-associated } \\
\text { neurodegeneration }\end{array}$ & $\begin{array}{l}\text { COASY on } \\
17 q 21.2\end{array}$ & $\begin{array}{l}\text { Autosomal } \\
\text { recessive }\end{array}$ & $\begin{array}{l}\text { Oromandibular dystonia with dysarthria, spastic } \\
\text { dystonic paraparesis, spastic bradykinetic-rigid } \\
\text { syndrome, distal areflexia }\end{array}$ & Oromandibular dystonia \\
\hline $\begin{array}{l}\text { PLA2G6-associated } \\
\text { neurodegeneration }\end{array}$ & $\begin{array}{l}\text { PLA2G6 on } \\
22 q 13.1\end{array}$ & $\begin{array}{l}\text { Autosomal } \\
\text { recessive }\end{array}$ & $\begin{array}{l}\text { Early-onset hypotonia, gait disturbance, cerebellar } \\
\text { ataxia, pyramidal signs, and early optic atrophy }\end{array}$ & $\begin{array}{l}\text { Two forms: } \\
\text { classic infantile neuroaxonal } \\
\text { dystrophy and atypical } \\
\text { neuroaxonal dystrophy } \\
\text { (adolescent onset) }\end{array}$ \\
\hline $\begin{array}{l}\text { Mitochondrial } \\
\text { membrane } \\
\text { protein-associated } \\
\text { neurodegeneration }\end{array}$ & $\begin{array}{l}\text { C19orf12 on } \\
19 q 12\end{array}$ & $\begin{array}{l}\text { Autosomal } \\
\text { recessive }\end{array}$ & $\begin{array}{l}\text { Slowly progressive spastic para/tetraparesis, } \\
\text { generalized dystonia, motor axonal neuropathy, } \\
\text { parkinsonism, psychiatric symptoms, retinal } \\
\text { abnormalities, and optic atrophy }\end{array}$ & Motor axonal neuropathy \\
\hline $\begin{array}{l}\text { Fatty acid } \\
\text { hydroxylase-associated } \\
\text { neurodegeneration }\end{array}$ & $\begin{array}{l}F A 2 H \text { on } \\
16 q 23.1\end{array}$ & $\begin{array}{l}\text { Autosomal } \\
\text { recessive }\end{array}$ & $\begin{array}{l}\text { Slowly progressive ataxia, dystonia, dysarthria, } \\
\text { spastic quadriplegia, and optic atrophy }\end{array}$ & Spastic paraplegia \\
\hline $\begin{array}{l}\text { B-propeller-associated } \\
\text { neurodegeneration }\end{array}$ & $\begin{array}{l}\text { WD repeat } \\
\text { domain } 45 \\
(\text { WDR } 45) \text { on } \\
\text { Xp11.23 }\end{array}$ & $\begin{array}{l}\text { X-linked } \\
\text { dominant }\end{array}$ & $\begin{array}{l}\text { Global developmental delay in early childhood } \\
\text { followed by dystonia, parkinsonism, cognitive } \\
\text { decline, and seizures in early adulthood. }\end{array}$ & $\begin{array}{l}\text { Very slowly progressive in } \\
\text { childhood }\end{array}$ \\
\hline Kufor-Rakeb & $\begin{array}{l}\text { ATP13A2 on } \\
1 \mathrm{p} 36.13\end{array}$ & $\begin{array}{l}\text { Autosomal } \\
\text { recessive }\end{array}$ & $\begin{array}{l}\text { Early-onset parkinsonism, pyramidal signs, } \\
\text { supranuclear gaze palsy, and dementia }\end{array}$ & $\begin{array}{l}\text { Can be responsive to levodopa } \\
\text { therapy }\end{array}$ \\
\hline $\begin{array}{l}\text { Hereditary } \\
\text { neuroferritinopathy }\end{array}$ & $\begin{array}{l}\text { FTL on } \\
19 q 13.33\end{array}$ & $\begin{array}{l}\text { Autosomal } \\
\text { dominant }\end{array}$ & Dystonia, parkinsonism, choreoathetosis & Adult onset \\
\hline Aceruloplasminemia & $C P$ on $3 q 24-25$ & $\begin{array}{l}\text { Autosomal } \\
\text { recessive }\end{array}$ & $\begin{array}{l}\text { Dysarthria, diabetes mellitus, retinal degeneration, } \\
\text { progression to dementia }\end{array}$ & $\begin{array}{l}\text { Adult onset; common in Japanese } \\
\text { population; laboratory studies } \\
\text { show high ferritin and low iron }\end{array}$ \\
\hline $\begin{array}{l}\text { Woodhouse-Sakati } \\
\text { syndrome }\end{array}$ & $\begin{array}{l}\text { DCAF17 } \\
(C 20 r f 37) \text { on } \\
2 \text { q31.1 }\end{array}$ & $\begin{array}{l}\text { Autosomal } \\
\text { recessive }\end{array}$ & $\begin{array}{l}\text { Generalized dystonia, cognitive impairment, } \\
\text { dysmorphic facial features, extraneurologic } \\
\text { involvement (hypogonadism, alopecia, and diabetes } \\
\text { mellitus) }\end{array}$ & $\begin{array}{l}\text { Endocrine abnormalities } \\
\text { common }\end{array}$ \\
\hline
\end{tabular}

protein-associated neurodegeneration is caused by a mutation in the C19orf12 gene, presenting with slowly progressive spastic para/tetraparesis, generalized dystonia, motor axonal neuropathy, parkinsonism, psychiatric symptoms, retinal abnormalities, and optic atrophy. ${ }^{4,5}$ Most of the latter features were lacking in our patient. Fatty acid hydroxylase-associated neurodegeneration is caused by mutations in the $\mathrm{FA} 2 \mathrm{H}$ gene, which is characterized clinically by slowly progressive ataxia, dystonia, dysarthria, spastic quadriplegia, and optic atrophy. ${ }^{4}$ Our patient did not have ataxia or optic atrophy. B-propellerassociated neurodegeneration is caused by mutation of the WDR45 gene. Though X-linked, it is always sporadic due to de novo mutation. ${ }^{4,5}$ Clinical features include global developmental delay in early childhood followed by dystonia, parkinsonism, cognitive decline, and seizures in early adulthood. Our patient's family history strongly suggested an autosomal recessive pattern. Kufor-Rakeb disease is caused by mutation of the ATP13A2 gene and presents with early-onset parkinsonism, pyramidal signs, altered eye movements, and dementia, which does not seem to fit well in this case. ${ }^{4} \mathrm{He}$ reditary neuroferritinopathy is an autosomal dominant disease leading to adult-onset dystonia and parkinsonism, unlike in our patient. ${ }^{4}$ Aceruloplasminemia is seen commonly in the Japanese population and presents with adult-onset dementia, diabetes mellitus, and retinal degeneration, accompanied by high serum ferritin and low serum iron concentration. ${ }^{4,5}$ Woodhouse-Sakati syndrome (WSS) is an autosomal recessive disease due to mutation in the DCAF17 (C2orf37) gene. It is characterized by generalized dystonia, cognitive impairment, and extraneurologic involvement (hypogonadism, alopecia, and diabetes mellitus). ${ }^{4,5}$ Maternal uncle and aunts of our patient had history of alopecia, although the patient did not have alopecia or any endocrine abnormalities.

\section{Question for consideration:}

1. What is the next step to achieve a definite diagnosis? 


\section{Section 3}

As there is a considerable overlap of the phenotypic features in these disorders, a next-generation sequencing panel is helpful to increase the diagnostic yield. However, in this particular case, based on the family history (autosomal recessive inheritance within a large consanguineous Arab family from the Middle East) and history of alopecia and cognitive difficulties in the affected family members, directed genetic testing for the DCAF17 gene showed homozygous deletion in exon 4 (c.436delC,p.Ala147Hisfs ${ }^{*} 9$ ), confirming the diagnosis of WSS. This is a common mutation in the Arab population. Both the patients' parents are carriers and her younger sister who was homozygous for this mutation was asymptomatic. Genetic counseling was provided to the family. She was treated with trihexyphenidyl for dystonia, which she did not tolerate well. A trial with levodopa-carbidopa was then initiated without much improvement of dystonia. She was screened for non-neurologic features found in WSS and endocrine, hearing, and swallowing evaluations were negative. The family had to return back to their home country due to social reasons.

\section{Discussion}

WSS is a rare autosomal recessive disorder that was first described in consanguineous Saudi families in 1983. ${ }^{7}$ WSS is caused by homozygous or compound heterozygous mutations in the DCAF17 gene, which codes a nucleolar protein with poorly understood function. c.436delC mutation in exon 4 of the DCAF17 gene as seen in our patient is considered a founder mutation. $^{8}$ Neurologic features include extrapyramidal involvement (i.e., dystonia, chorea, and gait abnormality), progressive cognitive decline, and sensorineural hearing loss. ${ }^{4,5,8}$ Brain MRI shows deposition of iron in the GP and sometimes SN. Leukoencephalopathy was described in about $50 \%$ of patients with the founder mutation. ${ }^{8}$ Endocrine abnormalities include primary hypogonadism, hypothyroidism, and diabetes mellitus. Other signs include alopecia, premature aging, hypodontia, and distinctive facial features (e.g., elongated triangular face, prominent ears, and prominent nasal root). ${ }^{8}$ There is a considerable amount of variability in patients with founder mutations, with neurologic symptoms starting from the first decade to adolescence and young adulthood. ${ }^{8}$ Treatment of WSS is symptomatic and should be managed by a multidisciplinary care team.

NBIA is a distinctive syndrome and MRI brain and genetic testing helps to narrow the differential diagnosis.

\section{Author contributions}

P.S. Ghosh: study concept and design. J. Alderson: acquisition of data. J. Alderson and P.S. Ghosh: analysis and interpretation. P.S. Ghosh: critical revision of the manuscript for important intellectual content. P.S. Ghosh: study supervision.

\section{Study funding}

No targeted funding reported.

\section{Disclosure}

J. Alderson reports no disclosures relevant to the manuscript. P.S. Ghosh received consulting fees from CVS Caremark, GLG Consulting, and Catalyst Pharmaceuticals. Go to Neurology. org/ $\mathrm{N}$ for full disclosures.

\section{References}

1. Meijer IA, Pearson TS. The twists of pediatric dystonia: phenomenology, classification, and genetics. Semin Pediatr Neurol 2018;25:65-74.

2. van Egmond ME, Kuiper A, Eggink $\mathrm{H}$, et al. Dystonia in children and adolescents: a systematic review and a new diagnostic algorithm. Jneurol Neurosurg Psychiatry 2015;86:774-781.

3. van Egmond ME, Lugtenberg CHA, Brouwer OF, et al. A post hoc study on gene panel analysis for the diagnosis of dystonia. Mov Disord 2017;32:569-575.

4. Di Meo I, Tiranti V. Classification and molecular pathogenesis of NBIA syndromes. Eur J Paediatr Neurol 2018;22:272-284.

5. Hayflick SJ, Kurian MA, Hogarth P. Neurodegeneration with brain iron accumulation. Handb Clin Neurol 2018;147:293-305.

6. Arber CE, Li A, Houlden H, Wray S. Review: insights into molecular mechanisms of disease in neurodegeneration with brain iron accumulation: unifying theories. Neuropathol Appl Neurobiol 2016;42:220-241.

7. Woodhouse NJ, Sakati NA. A syndrome of hypogonadism, alopecia, diabetes mellitus, mental retardation, deafness, and ECG abnormalities. J Med Genet 1983;20:216-219.

8. Almeqdadi M, Kemppainen JL, Pichurin PN, Gavrilova RH. Phenotypic variability of c.436delC DCAF17 gene mutation in Woodhouse-Sakati syndrome. Am J Case Rep 2018;19:347-353.

\section{Read Capitol Hill Report: Be Informed, Get Engaged}

From the halls of Congress to the offices of regulatory agencies, AAN members and advocacy staff are working tirelessly to represent the needs of you and your patients. Stay up to date with Capitol Hill Report at AAN.com/view/HillReport, or on Twitter at \#AANadvocacy. 


\section{Neurology}

\section{Clinical Reasoning: Seven-year-old girl with progressive gait difficulties Jillian Alderson and Partha S. Ghosh}

Neurology 2020;94;364-367 Published Online before print February 7, 2020

DOI 10.1212/WNL.0000000000009003

\section{This information is current as of February 7, 2020}

\section{Updated Information \&} Services

\section{References}

Subspecialty Collections

Permissions \& Licensing

\section{Reprints}

including high resolution figures, can be found at: http://n.neurology.org/content/94/8/364.full

This article cites 8 articles, 2 of which you can access for free at: http://n.neurology.org/content/94/8/364.full\#ref-list-1

This article, along with others on similar topics, appears in the following collection(s):

All Clinical Neurology

http://n.neurology.org/cgi/collection/all_clinical_neurology

All Pediatric

http://n.neurology.org/cgi/collection/all_pediatric

Dystonia

http://n.neurology.org/cgi/collection/dystonia

\section{MRI}

http://n.neurology.org/cgi/collection/mri

Information about reproducing this article in parts (figures,tables) or in its entirety can be found online at:

http://www.neurology.org/about/about_the_journal\#permissions

Information about ordering reprints can be found online:

http://n.neurology.org/subscribers/advertise

Neurology ${ }^{\circledR}$ is the official journal of the American Academy of Neurology. Published continuously since 1951, it is now a weekly with 48 issues per year. Copyright () 2020 American Academy of Neurology. All rights reserved. Print ISSN: 0028-3878. Online ISSN: 1526-632X.

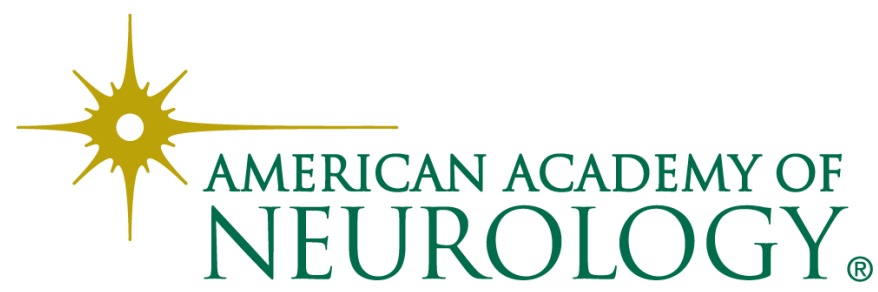

